\title{
Evaluation of mechanical properties of CAD/CAM ceramic systems: literature review
}

\author{
Avaliação das propriedades mecânicas dos sistemas \\ cerâmicos CAD/CAM: revisão de literatura
}

Ana Emanuela Cisne de LIMA1 iD https://orcid.org/0000-0002-0931-1978
Hilmo Barreto Leite FALCÃO FILHO² iD https://orcid.org/0000-0002-8928-3208
Helena de Freitas Oliveira PARANHOS1 ${ }_{\text {https://orcid.org/0000-0001-5766-6100 }}$

\section{ABSTRACT}

Computer aided design / computer aided manufacturing (CAD/CAM) systems are among the most technological advanced techniques in oral rehab today. Compared with conventional techniques, they can optimize the resistance and the adaptation of dental ceramics. Thus, their indications of use have been widened, making the technique more and more well-known and widespread. Therefore, the aim of this study is to present a literature review on comparative studies of the mechanical properties of ceramic systems produced by CAD / CAM. A search for scientific articles published between 2009 and 2019, in English, Spanish or Portuguese, was performed through the databases SCIELO, BIREME and PUBMED, using the descriptors "Ceramics", "Computer Aided Design" and " Partial Fixed Prosthesis ". Currently, all ceramic systems appear to have adequate strength for simple rehabilitations, but ceramic restorations produced by CAD/CAM systems present greater reliability than other manufacturing methods, presenting a wider array of indications due to their higher mechanical resistance. These systems, besides their versatility, also present an excellent aesthetic result, guaranteeing appropriate optical properties such as translucency and fluorescence, similar to natural teeth. Although the cost is a limiting factor, CAD/CAM technology is in full development and with high success rates that qualifies it as the state of art in oral rehabilitation.

Indexing terms: Ceramics. Computer-aided design. Fixed partial denture.

\section{RESUMO}

O sistema CAD-CAM (computer aided design/computer aided manufacturing), que significa desenho auxiliado por computação e manufatura auxiliada por computação, é um dos recursos mais tecnológicos e modernos na reabilitação oral atualmente. É uma alternativa que otimizou a resistência e a adaptação das cerâmicas odontológicas. Dessa maneira, suas indicações de uso têm-se ampliadas, tornando-o cada vez mais conhecido e difundido. O objetivo deste estudo é apresentar uma revisão da literatura sobre estudos comparativos das propriedades mecânicas dos sistemas cerâmicos produzidos por CAD/CAM. Foi realizada a busca de artigos científicos publicados entre 2009 e 2019, em inglês, espanhol ou português, nas bases de dados SCIELO, BIREME e PUBMED, utilizando os descritores: "Ceramics", "Computer Aided Design" e "Prótese Parcial Fixa". Atualmente todos os sistemas cerâmicos parecem ter uma adequada resistência para reabilitações simples, mas as restaurações cerâmicas produzidas por sistemas CAD/CAM apresentam

\footnotetext{
1 Universidade de São Paulo, Faculdade de Odontologia de Ribeirão Preto, Departamento de Materiais Dentários e Prótese. Av. do Café, s/n., Campus da USP, 14040-904, Ribeirão Preto, SP, Brasil. Correspondence to: AEC Lima. E-mail: <cisneemanuela@gmail.com>.

2 Universidade Federal do Ceará, Faculdade de Odontologia, Departamento de Odontologia. Fortaleza, CE, Brasil.

$\checkmark v$

How to cite this article

Lima AEC, Falcão Filho HBL, Paranhos HFO. Evaluation of mechanical properties of CAD/CAM ceramic systems: literature review. RGO, Rev Gaúch Odontol. 2020;68:e20200038. http://dx.doi.org/10.1590/1981-863720200003820200009
} 
maior confiabilidade do que outros métodos de fabricação; apresentando maiores possibilidades de indicações devido aos seus maiores valores de resistência mecânica. Esta tecnologia embora apresente o custo como um fator limitante, está em pleno desenvolvimento e já apresenta propriedades mecânicas suficientes e com índices de sucesso que a qualificam como o estado da arte em reabilitação oral.

Termos de indexação: Cerâmica. Desenho assistido por computador. Prótese parcial fixa.

\section{INTRODUCTION}

In recent decades, the increased cost of precious metals and number of patients with high aesthetic expectations have led to a growing demand for natural and fabricated restorations, thus boosting technological development and the emergence of new ceramic materials [1].

Working with these concepts once required a large amount of time, but with the modernization of the laboratory process associated with more accurate clinical techniques, rehabilitations started to be developed in a standardized way, increasing the performance with more quality [2]. Within this context, computer aided design/ computer aided manufacturing (CAD/CAM) technology emerged; an advanced system that allows the preparation of prostheses based on a three-dimensional design [3].

CAD/CAM is a technology introduced in dentistry in the late 1970 s by Bruce Altschuler in the USA, François Duret in France, and Werner Mormann and Marco Brandestini in Switzerland [4]. The implementation of CAD/CAM technology within various systems has affected not only "mass production" but also the improvement of the surgical procedure and restorations in general. These technologies promote dynamic interactions within the workflow, as well as generate a more reliable communication between clinical activity and laboratory activity, by exchanging data between CAD/CAM subsystems [3].

The main goal of CAD / CAM in restorative dentistry is the automation and mechanization of the ceramic making process. The conventional process of making demands time, skill of the laboratory technician and a larger percentage of defects. For example, the layering technique or craft technique presents a manual confection, where the production of a restoration is by mixing the porcelain powder with the modeling liquid on a glass plate until a paste is applied. with a brush over, for example, a refractory die. Given this processing, for example, it is clear which fragile and dependent is this conventional technique. Therefore one of the advantages of using the CAD-CAM system in this case is the fact that the infrastructure obtained from the partially sintered block ("dry press") has better quality (less defects). However, CAD / CAM has disadvantages, including the fact that restoration can not be done in layers with different colors and degrees of opacity, translucency, as occurs in the layer sintering method.

Two essential concepts based on high clinical performance can justify the use of CAD/CAM systems: the emphasis of the concept "minimally invasive dentistry", consisting of minimal and selective dental wear; and "zero fitting in prosthesis", implying minimal adjustments of the ceramic restorations performed clinically, thus allowing an efficient communication protocol with the prosthesis technician [2].

The production of a prosthesis by CAD/CAM follows the principles of mimicking the natural dentition; proper mastery over its functions and characteristics are necessary for the identification and evaluation of the clinical performance of prostheses under CAD/CAM. Thus, it is of fundamental importance to understand the mechanical behavior of the tooth when submitted to masticatory loads. In addition, the mechanical properties of dentin can be influenced by the area investigated, the orientation of the tubules, the tubular density and the age. The collagen matrix, for example, contributes to 25 to $30 \%$ of the tensile strength in human root dentin and 11 to $12 \%$ in human coronary dentin [5].

In a 3-point flexion test (coronary region, dentin and root), when the natural tooth is loaded, a flexural strength of 194.26 MPa was found in dentin and 152.86 $\mathrm{MPa}$ in the coronary region. In comparison, the flexural strength of the root was found to be $224.86 \mathrm{MPa}$. The fact that the flexural strength of the human root dentin is significantly greater than the resistance of the coronary dentin is probably due to the approximately parallel alignment of the tubules in the root dentine and the relative consistency of their diameter in the long axis, thus providing a greater homogeneity in the distribution of the perineal and intertubular dentin [5].

The mechanical strength of ceramic systems varies according to their chemical and physical characteristics. 
CAD/CAM systems have substantially increased the strength of metal-free restorations, which has led to increased longevity of the restorations. A study of the mechanical properties of the ceramic systems is fundamental to strengthen its credibility and safety for various indications [6]. The aim of this study is to perform a review of the literature on the mechanical properties of CAD/CAM systems.

\section{Characteristics of CAD/CAM systems}

Several CAD/CAM systems are currently available on the market (chart 1), developed based on an initial reading system, planning software (CAD) and a milling system (CAM). Within the national and international market there are several types of CAD/CAM systems (chart 1); however, according to Amaroso et al. [7] the three most used systems in Brazilian dentistry are Procera, Lava and CEREC.

The systems consist of a high-precision scanner, which acquires a digital image of a dental cast or from the patient's own dental arch. This 3D virtual scan is processed by a trained professional who builds a digital model of the structure that is to be manufactured (e.g. a crown) using a dedicated software program. Subsequently the "part" is sent to the printer, which is a milling unit, to form presynthesized ceramic blocks. Then, the piece is polished and applied in the mouth [8].

Therefore, the aim of this study is to present a literature review on comparative studies of the mechanical properties of ceramic systems produced by CAD / CAM.

Chart 1. Non-exhaustive overview of commercially available CAD/CAM systems.

\begin{tabular}{ll}
\hline Systems & \multicolumn{1}{c}{ Companies } \\
\hline CEREC 3D $^{\oplus}$ CEREC InLab $^{\oplus}$ & Sirona Dental Systems GmbH, Germany \\
Procera $^{\circledast}$ & Nobelbiocare AB, Sweden \\
Everest $^{\oplus}$ & KaVo Dental GmbH, Germany \\
Lava $^{\circledR}$ & 3MESPE, Germany \\
DigiDent $^{\circledast}$ & Hint-Els GmbH, Germany \\
Cercon $^{\circledast}$ & Degudent GmbH, Germany \\
Evolution 4D $^{\circledast}$ & D4D Technologie, USA \\
Etkon $^{\circledast}$ & Etkon, Germany \\
Precident DCS $^{\circledast}$ & DCS, Switzerland \\
Pro 50 & Cynovad, Canada \\
Wol-Ceram & Wol-Dent, Germany \\
\hline
\end{tabular}

In addition, this review shows some results of studies on the mechanical properties of CAD/CAM ceramic systems, comparing them with the conventional technique of making dental ceramics.

A search for scientific articles published between 2009 and 2019, in English, Spanish or Portuguese, was performed through the databases SCIELO, BIREME and PUBMED, using the descriptors "Ceramics", "Computer Aided Design" and "Partial Fixed Prosthesis ". The search yielded 64 articles about in vitro studies CAD/CAM ceramics, from which 37 were selected after reading titles and abstracts and excluding those that did not involve some method of evaluation of the mechanical properties of these systems.

\section{Type of test performed}

An important factor in any dental prosthesis planning is resistance, a mechanical property attributed to any material that ensures that the prosthetic part meets physiological functions, safely and with longevity. Resistance refers to the material's ability to resist induced stresses, without any fracture or permanent deformation, in other words, this material must have a certain elastic tension to withstand these stresses. The mechanical properties can be quantified through some tests; they are: tensile stress (the material is subjected to a force that tends to stretch or lengthen the body), compression stress (the material is subjected to a compressive force on an axis of the body), shear stress (the material tends to resist the sliding of a portion of a body over another) and flexural strength (the material tends to resist the bending stress).

In a recent (2015) systematic review, including 67 clinical cases using CAD/CAM, clinical fracture rates after 5 years of up to $18.4 \%, 5.5 \%$ and $1.7 \%$ (chart 2) were reported for crowns made of feldspathic ceramics, reinforced glass ceramics and densely sintered zirconia, respectively [9]. Pjetursson [10] evaluated the 5-year clinical fracture rates for multiple fixed dental prostheses, which were $15.3 \%$ for enhanced glass ceramics and up to $3.2 \%$ for densely sintered zirconia (chart 2).

When evaluating fatigue strength degradation in ceramic materials made by conventional laboratory processing using a protocol of 20,000 cycles at a frequency of $0.5 \mathrm{~Hz}$, Belli et al. [11] showed a value of $440 \mathrm{MPa}$ for Y-TZP (polystyrene tetragonal zirconia stabilized with 
yttria), $121 \mathrm{MPa}$ for lithium disilicate used for CAD/CAM, and $38 \mathrm{MPa}$ for feldspathic used for CAD/CAM: $38 \mathrm{MPa}$ (chart 2).

Due to the characteristics of resistance, translucency and color diversity, vitreous ceramics based on lithium disilicate can be used for the manufacturing of monolithic restorations or infrastructures for subsequent coating. Clinical results of monolithic CAD/CAM restorations made with vitreous ceramics enhanced by lithium disilicate showed a survival rate of $97 \%$ after 7 years [1].

In a study by Belli et al. [11], within a 3.5-year period, 1.4\% (7 of 491) all-ceramic restorations fractured. Regarding the types of ceramics produced by CAD/CAM, for the observed period, lithium disilicate presented a slightly higher failure rate (presence of cracks or fracture in the prosthetic part) for the unit crowns (1.23\% failure) compared with the onlays $(0.71 \%$ failure) and inlays $(0.36 \%$ failure). Regarding fixed partial prostheses, the survival of lithium disilicate-coated zirconia was lower (3.93\% failure) than that of porcelain-covered zirconia ( $0.82 \%$ failure) and monolithic zirconia (no failure); a summary of these findings is shown in chart 2 .

In a literature review, the flexural strength of feldspar ceramics presented the lowest values of strength in relation to the other types of ceramics mentioned. Lithium disilicate (LD) for injection (e.max® Press) had the lowest reduction in resistance after undergoing flexion test with $29.6 \%$, whereas lithium disilicate for milling (e.max® CAD) showed a reduction of $53.4 \%$ [12].

André et al. (2006) e Ferruzzi et al. (2018) [12,13] investigated monolithic blocks of lithium disilicatereinforced ceramics after milling and crystallization at $840{ }^{\circ} \mathrm{C}$, showing that lithium disilicate crystals grow in a controlled manner to $70 \%$ of the material volume, after which the color remains unchanged and the strength is about $360 \mathrm{MPa}$, according of flexural resistance (chart 4). This result is reaffirmed by Padua et al. [14], who found that these high-strength or lithium disilicate-reinforced vitreous ceramics can have from 260 to $540 \mathrm{MPa}$ of flexural strength (chart 3).

Using FESEM (Field-emission Scanning Electron Microscopy), Fraga et al. [15] showed defects on CAD/ CAM machining surfaces, as well as increased surface roughness and significantly reduced flexural strength in all the investigated ceramics, compared with a postmachining polished ceramic. However, after polishing, the surface was smoothened and the experimental hypothesis of increasing the resistance of CAD/CAM-produced

Chart 2. Clinical failure rate in crowns made by CAD/CAM.

\begin{tabular}{|c|c|c|c|c|}
\hline Authors/year & Type of ceramics & Study & Relevant information & Results \\
\hline Sailer et al. [9] & $\begin{array}{l}\text { Feldspatic } \\
\text { Reinforced glass ceramics } \\
\text { Zirconia }\end{array}$ & $\begin{array}{l}\text { Fracture rate of } 5 \text { years (presence of } \\
\text { cracks or fracture in the prosthetic part) }\end{array}$ & 67 clinical studies & $\begin{array}{l}18.4 \% \\
5.5 \% \\
1.7 \%\end{array}$ \\
\hline Pjetursson et al. [10] & $\begin{array}{l}\text { Reinforced glass-ceramic } \\
\text { Densely sintered zirconia }\end{array}$ & $\begin{array}{l}\text { Fracture rate of } 5 \text { years (presence of } \\
\text { cracks or fracture in the prosthetic part) }\end{array}$ & Multiple fixed dental prostheses & $\begin{array}{l}15.3 \% \\
3.2 \%\end{array}$ \\
\hline Belli et al. [11] & $\begin{array}{l}\text { Single crowns } \\
\text { Onlays } \\
\text { Inlays }\end{array}$ & $\begin{array}{l}\text { Clinical observational study - } 3.5 \text { years } \\
\text { (Presence of cracks or fracture in the } \\
\text { prosthetic part) }\end{array}$ & $\begin{array}{l}\text { Fixed single or partial crowns } \\
\text { made with lithium disilicate }\end{array}$ & $\begin{array}{l}1.23 \% \\
0.71 \% \\
0.36 \%\end{array}$ \\
\hline Belli et al. [11] & $\begin{array}{l}\text { Zirconia coated with lithium disilicate } \\
\text { Zirconia covered by porcelain } \\
\text { Monolithic zirconia }\end{array}$ & $\begin{array}{l}\text { Clinical observational study - } 3.5 \text { years } \\
\text { (Presence of cracks or fracture in the } \\
\text { prosthetic part) }\end{array}$ & Fixed partial prostheses & $\begin{array}{c}3.93 \% \\
0.82 \% \\
\text { no failure }\end{array}$ \\
\hline
\end{tabular}

Chart 3. Values of flexural strength of crowns made by CAD/CAM after machining versus machining and polishing.

\begin{tabular}{|c|c|c|c|c|}
\hline Authors/year & Type of ceramics & Measured index & Relevant information & Results \\
\hline \multirow[t]{2}{*}{ Fraga et al. [15] } & Glass-ceramics enhanced by leucite & Biaxial flexural strength & Hard cutting & $128.20 \mathrm{Mpa}$ \\
\hline & & & Machining followed by polishing & $177.2 \mathrm{MPa}$ \\
\hline Pádua et al. [14] & $\begin{array}{l}\text { High strength vitreous ceramics or reinforced by } \\
\text { lithium disilicate }\end{array}$ & Flexural resistance & Values found after milling & 260 to $540 \mathrm{MPa}$ \\
\hline
\end{tabular}


ceramics was accepted. The same study showed that hard-cut machining resulted in a $27 \%$ lower biaxial flexural strength (128.2 MPa) of a leucite-reinforced glass-ceramic compared with machining followed by polishing (177.2 MPa). Using scanning electron microscopy (SEM) of the cross-section of the disks, it was observed that machining introduced defects in the ceramic surface, which were removed by polishing. The average roughness of the machined group was $1.37 \mu \mathrm{m}$, while that of the machined and polished group was $0.04 \mu \mathrm{m}$ (chart 3).

\section{DISCUSSION}

\section{CAD/CAM x Conventional Laboratory Processing}

Chart 4. Comparative values of the flexural strength of the dentin-enamel complex, fracture strength of the metallic infrastructures and flexural strength of the ceramic crowns made by conventional laboratory processing and CAD/CAM crowns.

It can be noticed in chart 4 that crowns made with zirconia showed a flexural resistance well above the value found in the three dental portions (dentine, coronary portion and root portion), indicating that this type of material can be suitable for posterior teeth, where they receive the highest masticatory load. Chart 4 shows flexural strength values of $768 \mathrm{MPa}$ for CAD/CAM-processed zirconia crowns and $440 \mathrm{MPa}$ for zirconia crowns made by conventional laboratory processing.

Regarding feldspathic ceramics, it can be seen in chart 4 that both CAD/CAM and conventional laboratory processing result in low flexural strength (66 Mpa and 121 Mpa, respectively). Therefore, these ceramics are suitable for coating cosmetic cores or ceramic laminates, for example.
When comparing the values of flexural strength of ceramics produced by CAD/CAM and metal infrastructures, it can be seen that strength obtained by CAD/CAM are closer to those of the dentin-enamel complex. Thus, the practicality of CAD/CAM together with its accuracy in terms of mechanical properties and adaptation, have been major factor in its increasing popularity.

\section{Types of comparison}

Ceramics are materials that bear almost no elastic deformation; consequently, they fracture suddenly and irreversibly. Defects present in this material can act as points of concentration of stresses, initiating the propagation of a crack when the stored elastic energy exceeds a threshold [13].

According to Ferruzzi et al. [13], a high value of flexural strength was exhibited by lithium disilicate ceramics (e.max ${ }^{\circledR}$ Press, $360 \mathrm{MPa}$ ) and zirconia ceramics (768 Mpa). Clinically, these two types of ceramics fit into various clinical applications (Chart 4), it is therefore apparent that crowns milled from a CAD/CAM system can have a great mechanical advantage compared with crowns made by injection or pressing, for example (Chart 4).

Belli et al. [11], found that the flexural strength of lithium disilicate ceramics made by conventional laboratory processing was $121 \mathrm{MPa}$, reaffirming the result found by Ferruzzi et al. [13] that CAD/CAM significantly increases the flexural strength of the ceramic material. He also observed the failure of crowns in an observational study of 3.5 years, finding a low fracture index for these ceramics, with zirconia covered by lithium disilicate showing the highest failure rate (3.93\% of 491 prostheses) (chart 4).

Fraga et al. [15] indicated that only CAD/CAM milling is not enough to consolidate and guarantee the mechanical properties of dental ceramics. Although CAD/

Chart 4. Comparative values of the flexural strength of the dentin-enamel complex, fracture strength of the metallic infrastructures and flexural strength of the ceramic crowns made by conventional laboratory processing and CAD/CAM crowns.

\begin{tabular}{llll}
\hline Dentin-enamel complex & $\begin{array}{c}\text { Metal infrastructures - Molten } \\
\text { metal core }\end{array}$ & $\begin{array}{c}\text { Crowns for conventional laboratory } \\
\text { processing }\end{array}$ & $\begin{array}{c}\text { CAD/CAM } \\
\text { Crowns }\end{array}$ \\
\hline Schlichting et al. [16] & Porto et al. [17] & Belli et al. [11] & Ferruzzi et al. [13] \\
- Dentine: $194.26 \mathrm{MPa}$ & Conventional laboratory & - Lithium Dissilicate: $121 \mathrm{MPa}$ & - Feldspaths: $66 \mathrm{MPa}$ \\
- Coronary portion: $152.86 \mathrm{MPa}$ & processing: $939.61 \mathrm{MPa}$ & - Feldspathic: $38 \mathrm{MPa}$ & - Leucite Strengthened Feldspaths: $85 \mathrm{MPa}$ \\
- Root portion: $224.86 \mathrm{MPa}$ & & - Yttrium stabilized polycrystalline & - Lithium Dissilicate (e.max ${ }^{\circledR}$ Press): $360 \mathrm{Mpa}$ \\
& & tetragonal zirconia: $440 \mathrm{MPa}$ & - Zirconia: $768 \mathrm{MPa}$ \\
\hline
\end{tabular}


CAM showed a lower degree of surface defects, the presence of defects may cause propagation of a possible failure. They also stated that hard-cut machining reduced the biaxial flexural strength of a leucite-enhanced vitreous ceramic by about $27 \%$ when compared to machining followed by polishing (Chart 3).

Pádua et al. [14] reaffirmed the results found in almost all studies: an increase of flexural strength by CAD/ CAM systems compared with traditional manufacturing (Chart 3).

The strength of ceramics depends on the size, number and distribution of defects in the area with the highest tensile stress concentration, as well as the ability of the material to withstand the rapid propagation of the crack (fracture toughness). Some examples of defects that can be found in ceramics are: pores, cracks, inclusions, as well as surface defects due to wear and machining $[4,5,13]$.

\section{Composition and failure about CAD/CAM ceramics}

In view of the constant stress that restorative materials are subjected to in the buccal environment, in the presence of salivary moisture, fillers and masticatory forces and changes in temperature and $\mathrm{pH}$, restorations tend to fail due to a phenomenon called fatigue, i.e. the failure of a material subjected to stresses or deformations over a period of time [15]. The composition and the conformation of each ceramic confers to its mechanical properties, which can favor or hinder the development of factures by fatigue [18] (chart 5).

Regarding the study of mechanical properties of ceramic materials, cyclic fatigue tests can reproduce a condition that is close to what occurs clinically. Thus, it is possible to acquire and develop a clinical view of possible variables that the ceramic prosthesis can suffer from in the buccal environment $[12,13]$.

Cracks tend to propagate at points of greatest tensile stress. Although a ceramic restoration can fracture abruptly from a single intense overload, the failure is more likely to occur cumulatively after a prolonged period of seemingly innocuous but lower-load events. Such fractures are manifested in the clinical literature as 'lifetime' or 'survival rate' [15-17].

When a monolithic ceramic is manufactured, to make it resistant to cracking without interfering with the aesthetic properties, the goal is to avoid weak veneer/ core interfaces, minimizing the risk of delamination. Some examples of ceramics in this condition are: lithium disilicate glass-ceramic (IPS e.max Press or CAD by Ivoclar-Vivadent), fine-grained zirconia (e.g. Lava Plus from 3M ESPE, Bruxzir from Glidewell, Allzir from New Image) and surface-infiltrated glass (chart 6) $[15,18,19]$.

Chart 5. Mechanical properties of dental ceramics $[12,13]$.

\begin{tabular}{lccc}
\hline & Modulus of elasticity (GPa) & Flexural strength (MPa) & Fracture toughness (Mpa.m-2) \\
\hline Feldspathic Ceramics & $45-70$ & 66 & $0.7-1,1$ \\
Reinforced by leucite - addition of leucite at a ratio of 35 to $45 \%$ & $65-86$ & 85 & 1.3 \\
Reinforced by Lithium & $95-96$ & 360 & 2.75 (Press) \\
Dissilicate & & 2.25 (CAD) \\
Zirconia & 210 & 768 & $5.5-7$ \\
\hline
\end{tabular}

Chart 6. Composition and indications of ceramics enhanced by lithium disilicate.

\begin{tabular}{|c|c|c|c|c|}
\hline & $\%$ (Weight) glassy phase & Crystalline structure & Composition & Indication \\
\hline e.max $C A D$ & $30 \%$ & $\begin{array}{l}\text { Lithium disilicate crystals } \\
\text { (0.5 to } 4 \mu \mathrm{m})\end{array}$ & $\begin{array}{l}57-80 \% \mathrm{SiO}_{2} \\
11-19 \% \mathrm{LiO}_{2} \\
0-13 \% \mathrm{~K}_{2} \mathrm{O}_{1} \\
\mathrm{P}_{2} \mathrm{O}_{5}, \mathrm{ZrO}_{2}, \mathrm{ZnO}, \mathrm{AL}_{2} \mathrm{O}_{3}, \mathrm{MgO} \\
\text { and coloured oxides. }\end{array}$ & $\begin{array}{l}\text { Inlays } \\
\text { Onlays } \\
\text { Facets } \\
\text { Total crowns anterior and posterior } \\
\text { Fixed prosthesis anterior and posterior, up to the } \\
\text { first molar }\end{array}$ \\
\hline IPS e.max Zircad & $\cong 1 \%$ & $\begin{array}{l}\text { Yttria stabilized } \\
\text { polycrystalline } \\
\text { tetragonal zirconia }\end{array}$ & $\begin{array}{l}95 \% \mathrm{ZrO}_{2}, 5 \% \\
\mathrm{HfO}_{2}+\mathrm{Al}_{2} \mathrm{O}_{3}+\mathrm{Y}_{2} \mathrm{O}_{3}+\text { others, } \\
\mathrm{Rh}_{2} \mathrm{O}_{3}+\mathrm{Al}_{2} \mathrm{O}_{3}+\mathrm{Y}_{2} \mathrm{O}_{3}\end{array}$ & Crown infrastructure Partial dentures in all regions \\
\hline
\end{tabular}


André et al. [12] e Ferruzzi et al. [13] showed that, currently, lithium disilicate-reinforced ceramics are also available in the form of partially crystallized blocks for CAD/CAM manufacturing (e.max ${ }^{\circledR} C A D$, Ivoclar Vivadent ${ }^{\circledR}$ ). The blocks are available in a size compatible with unitary restorations. Partial crystallization allows fast and easy milling. In this phase lithium metasilicate crystals are formed, showing more favorable processing properties, although the ceramic already presents high resistance (from 130 to $150 \mathrm{MPa}$ ) and is able to guarantee intact margins. In this context, the increase in flexural strength between dentures made by CAD/CAM and natural teeth is also of importance.

Fractures occur when the stresses imposed on a given material are greater than the cohesive forces existing between the atoms that compose it, that is, when it is submitted to tensions superior to its fracture resistance limit. Values of fracture strength of dental ceramics indicated for the posterior region are between 160 and $1300 \mathrm{MPa}$. Considering the contact areas in posterior teeth, even under an extreme load of e.g. 3,500N, the contact pressures during usual maximum intercuspation reach around $55 \mathrm{MPa}$ in women and $67 \mathrm{MPa}$ in men (chart 5) $[15,20-22]$.

It is necessary to understand that the resistance to fracture of a material can be diminished by the presence of defects or cracks, often imperceptible, that act as factors of concentration of tensions. Failures in ceramics are often associated with existing defects $[15,16]$.

When stress values approach the flexural strength value, so-called cracks are observed in monolithic structures. When viewed from the top, they have a starry appearance. Radial cracks can propagate throughout the thickness of the material, reach the side walls or penetrate the substrate on which the ceramic material is cemented. They are identified as the probable responsible for catastrophic failures (complete fracture) in monolithic crowns [15,23-25].

Recently, due to the development of ceramic materials with improved mechanical properties and the practicality introduced by CAD/CAM systems, it is possible to obtain aesthetics and strength. Reinforced single-layer materials can be characterized with extrinsic paint and exhibit satisfactory aesthetic performance. In addition to dispensing ceramic coating, such restorations have been shown to have increased toughness to masticatory efforts $[14,15,26-30]$.
CAD/CAM technology provides powerful restoration and conservative preparation; however, for best performance the materials should be chosen during the treatment planning. The digital system allows preparations that are less complex and also less invasive; in addition, it provides the same strength of other treatment options. Studies have shown unexpected behavior like the higher fatigue resistance of polymer-based materials when compared with that of ceramics. The flexural modulus of polymer-based materials is very similar to that of dentin, which creates a single body in regarding mechanical behavior, and consequently polymer-based materials can be widely used [31-38].

\section{CONCLUSION}

It can be stated that prefabricated monolithic blocks for CAD/CAM show a lower concentration of defects, which can still be introduced during manipulation due to adjustments with rotary instruments or due to masticatory activity. In this context, the increase in flexural strength between dentures made by CAD/CAM compared with natural teeth, except for feldspathic ceramics, is also relevant. The mechanical strength of these systems indicates their reliability for clinical indications; however, more randomized controlled clinical trials with longitudinal analyzes including different biological variables are necessary to consolidate the clinical success of these materials.

\section{Collaborators}

AEC LIMA, preparation and design of the study; development and writing of the manuscript; data analysis and interpretation and revision of the manuscript. HBL FALCÃO FILHO, preparation and design of the study; data analysis and interpretation and revision of the manuscript. HFO PARANHOS, data analysis and interpretation and revision of the manuscript.

\section{REFERENCES}

1. Denry I, Kelly JR. Emerging ceramic-based materials for dentistry. J. Dent. Res. 2014;(93):1235-1242. http://dx.doi. org/10.1177/0022034514553627

2. Pérez CC, Duque JV. CAD-CAM. Restorations systems and ceramics: a review. Faculdade Odontol Univ Antioq. 2010;(22):88-108. 
3. Campos ML, Valverde $\mathrm{YF}$, Cisneros $\mathrm{R}$, Andamayo DC. Adaptación de cofias metálicas confeccionadas con das técnicas: cera pérdida colada por centrifugación convencional y fresado de bloque blando en CAD/CAM. Rev Estomatol Herediana. 2017;(27):163-175. http://dx.doi.org/10.20453/ reh.v27i3.3200

4. Alves VM, Oliveira RS, Cecilio OL, Neto Ol, Castro SHD. Advantages $x$ disadvantages of system cad / cam. Braz J Surg Clinical Res. 2017;(18):106-109.

5. Lopes MB, Sinhoreti MAC, Correr Sobrinho L, Consani S. Estudo comparativo do tipo de substrato dental utilizado em testes de resistência de união ao cisalhamento. Pesq Odontol Bras. 2003;17(2):171-175. http://dx.doi.org/10.1590/s151774912003000200014

6. Fraga S, Amaral M, Bottino MA, Valandro LF, Kleverlaan CJ, May LG. Impact of machining on the flexural fatigue strength of glass and polycrystalline CAD/CAM ceramics. Dental Mat. 2017;33(11):1286-1297. http://dx.doi.org/10.1016/J. DENTAL.2017.07.019

7. Amaroso AP, Ferreira MB, Torcato LB, Pellizzer EP, Mazaro JVQ, Gennari Filho H. Cerâmicas odontológicas: propriedades, indicações e considerações clínicas. Rev Odontol Araçatuba. 2012;33(2):19-25.

8. Carvalho RLA, Faria JCB, Carvalho RF, Cruz FLG, Goyta FR. Indicações, adaptação marginal e longevidade clínica de sistemas cerâmicos livres de metal: uma revisão da literatura. Int J Dent. Recife, 2012(11):1.

9. Sailer I, Makarov NA, Thoma DS, Zwahlen M, Pjetursson BE. All-ceramic or metal-ceramic tooth-supported fixed dental prostheses (FDPs)? A systematic review of the survival and complication rates. Part I: Single crowns (SCs). Dent. Mater. J. 2015; (31):603-623. http://dx.doi.org/10.1016/j.dental. 2015.02.01

10. Pjetursson BE, Sailer I, Makarov NA, Zwahlen M, Thoma, DS All-ceramic or metal-ceramic tooth-supported fixed dental prostheses (FDPs)? A systematic review of the survival and complication rates. Part II: Multiple-unit FDPs. Dent. Mater. J. 2015; 31(6): 624-639. http://dx.doi.org/10.1016/J.DENTAL. 2015.02.013

11. Belli UR, Petschelt $A B$, Hofner JHSL. Fracture rates and lifetime estimations of CAD/CAM all-ceramic restorations. J. Dent. Res. 2016; (95): 67-73. http://dx.doi.org/10.1177/002 2034515608187

12. Ferruzzi F, Ferrairo BM, Piras FF, Borges AFS, Rubo JH. Fatigue survival and damage modes of lithium disilicate and resin nanoceramic crowns. J. Appl. Oral Sci. 2019; 27: e20180297. http://dx.doi.org/10.1590/1678-7757-2018-0297

13. André J, Cardoso P, Fernando C, Leal CS. CAD-CAM: a informática a serviço da prótese fixa. Rev. Odontol. da UNESP. 2006; 35: 183-190. http://dx.doi.org/10.1145/3025171.30 25190

14. Ferruzzi F, Ferrairo BM, Piras FF, Borges AFS, Rubo JH. Fatigue survival and damage modes of lithium disilicate and resin nanoceramic crowns. J. Appl. Oral Sci. 2019; 27: e20180297. http://dx.doi.org/10.1590/1678-7757-2018-0297

15. Pádua JM, Teles RF. CAD/CAM No Laboratório e Na Clínica: a Odontologia Digital. São Paulo. Editora: Napoleão Livros; 2017. Cap. 3.
16. Fraga $S$, Amaral $M$, Bottino $M A$, Valandro LF, Kleverlaan CJ, May LG. Impact of machining on the flexural fatigue strength of glass and polycrystalline CAD/CAM ceramics. Dent. Mater. J. 2017; 33(11): 1286-1297. http://dx.doi.org/10.1016/J.DENTAL. 2017.07.019

17. Schlichting LH, Maia HP, Baratieri LN, Magne P. Novel-design ultra-thin CAD/CAM composite resin and ceramic occlusal veneers for the treatment of severe dental erosion. J Prosthet Dent. 2011: 217-226. http://dx.doi.org/10.1016/S0022-3913 (11)60035-8

18. Porto TS, Roperto RC, Akkus A, Akkus O, Teich S, Faddoul F, et al. Effect of storage and aging conditions on the flexural strength and flexural modulus of CAD/CAM materials. Dent Mater J. 2019; 38(2):264-70. http://dx.doi.org/10.4012/dmj. 2018-111

19. Bonfante EA, Coelho PG. A Critical Perspective on Mechanical Testing of Implants and Prostheses. J Dent Res. 2016; (28):18-27. http://dx.doi.org/10.1177/0022034515624445

20. Zhang Y, Sailer, I. \& Lawn, B. R. Fatigue of dental ceramics J Dent. 2013; (41):1135-1147. http://dx.doi.org/10.1016/j. jdent.2013.10.007

21. Paulillo AMS, Felizardo, MLG. Avaliação das propriedades mecânicas de resinas compostas indiretas confeccionadas através do sistema cad/cam. In: XXIII Congresso de Iniciação Científica da UNICAMP. Campinas, 2015. http://dx.doi.org/10. 19146/pibic-2015-37588

22. Azar B, Eckert S, Kunkela J, Ingr T, Mounajjed R. The marginal fit of lithium disilicate crowns: Press vs. CAD/CAM. Brazilian Oral Resear. 2018; 32(0):1-7. http://dx.doi.org/10.1590/18073107/2018.vol32.0001

23. Bernardes SR, Tiossi R, Sartori IAM, Thomé G. Tecnologia CAD / CAM aplicada a prótese dentária e sobre implantes: o que é, como funciona, vantagens e limitações. Revisão crítica da literatura. Jornal ILAPEO. 2014: 6(1).

24. Carvalho AO, Bruzi G, Giannini M, Magne P. Fatigue resistance of CAD/CAM complete crowns with a simplified cementation process. J Prosthet Dent. 2014; 111(4): 310-317. http://dx.doi.org/10.1016/j.prosdent.2013.09.020

25. Dias AMS, Miranda JS, Godoy GC. Avaliação da tenacidade à fratura através do ensaio de indentação em pastilhas de metal duro. Matéria. 2009; 14(2): 869-877.

26. Jeong $Y G$, Lee WS, Lee KB. Accuracy evaluation of dental models manufactured by CAD/CAM milling method and 3D printing method. J Adv Prosthodont. 2018; 10(3): 245. http://dx.doi.org/10.4047/jap.2018.10.3.245

27. Hilgert LA, Beuer JSF, Andrada MACA, Araújo, DEE. Odontologia Restauradora com Sistemas CAD / CAM: O Estado Atual da Arte Parte 2 - Possibilidades Restauradoras e Sistemas CAD/CAM. 2009; 5(4):424-435

28. Li RWK, Chow TW, Matinlinna JP. Ceramic dental biomaterials and CAD/CAM technology: State of the art. J Prosthodont Res. 2014. http://dx.doi.org/10.1016/j.jpor.2014.07.003

29. Lim K, Yap AUJ, Agarwalla SV, Tan KBC, Rosa V. Reliability, failure probability, and strength of resin-based materials for CAD/CAM restorations. J Appl Oral Sci. 2016; 24(5): 447-452. http://dx.doi.org/10.1590/1678-775720150561 
30. Nagarkar SR., Perdigão J, Seong WJ, Theis-Mahon N. Digital versus conventional impressions for full-coverage restorations: A systematic review and meta-analysis. JADA. 2018; 149(2): 139-147.e1. http://dx.doi.org/10.1016/j.adaj.2017.10.001

31. Piccoli AC, Borba M, Piccoli AC, Borba M. Influence of the fabrication method on the fracture behavior of all-ceramic prosthesis. Cerâmica. 2018; 64(370): 284-287. http://dx.doi. org/10.1590/0366-69132018643702371

32. Porto T, Roperto R, Akkus A, Akkus O, Porto-Neto S, Teich S, et al. Campos, E. Mechanical properties and DIC analyses of CAD/CAM materials. JCED. 2016; 8(5):512-516. http://dx. doi.org/10.4317/jced.53014

33. Ramos, Carla Müller. Propriedades mecânicas e caracterização intrínseca de zircônia experimental para uso em sistemas CAD/ CAM. Bauru. Rev. Fac. Odontol. Bauru. 2013; 1: 55-60. http:// dx.doi.org/10.11606/D.25.2013.tde-03092013-155032

34. Carvalho AO, Bruzi G, Giannini M, Magne P. Fatigue resistance of CAD/CAM complete crowns with a simplified cementation process. J Prosthet Dent. 2014; 111(4):310-7. http://dx.doi. org/10.1016/j.prosdent.2013.09.020

35. Porto TS, Roperto RC, Teich ST, Faddoul FF, Rizzante FAP, Porto-Neto ST, et al. Brittleness index and its relationship with materials mechanical properties: Influence on the machinability of CAD/CAM materials. Braz Oral Res. 2019; 33(0):e026. http://dx.doi.org/10.1590/1807-3107bor-2019. vol33.0026

36. Suarez MJJ, Vernimmen FS, Merchan EAR. Comparación de la precisión marginal de cofias de zirconia entre los sistemas CAD/CAM Cerec InLab (Sirona ${ }^{\circledR}$ ), CAD/CAM Zirkonzahn (Zirkonzahn ${ }^{\circledR}$ ) y sistema pantográfico Zirkograph 025 ECO (Zirkonzahn ${ }^{\circledR}$ ). Rev. Odont. Mex. 2015;19(4):240-245. http:// dx.doi.org/10.1016/j.rodmex.2015.10.005

37. Suputtamongkol K, Anusavice KJ, Suchatlampong C, Sithiamnuai P, Tulapornchai C. Clinical performance and wear characteristics of veneered lithia-disilicate-based ceramic crowns. Dent. Mater. J. 2008; 24(5): 667-673. http://dx.doi. org/10.1016/j.dental.2007.06.033

38. Zhao K, Wei YR, Pan Y, Zhang XP, Swain MV, Guess PC. Influence of veneer and cyclic loading on failure behavior of lithium disilicate glass-ceramic molar crowns. Dent. Mater. J. 2014; 30(2):164-171. http://dx.doi.org/10.1016/j. dental.2013.11.001

Received on: 21/2/2020 Final version resubmitted on: 2/4/2020 Approved on: 15/4/2020 